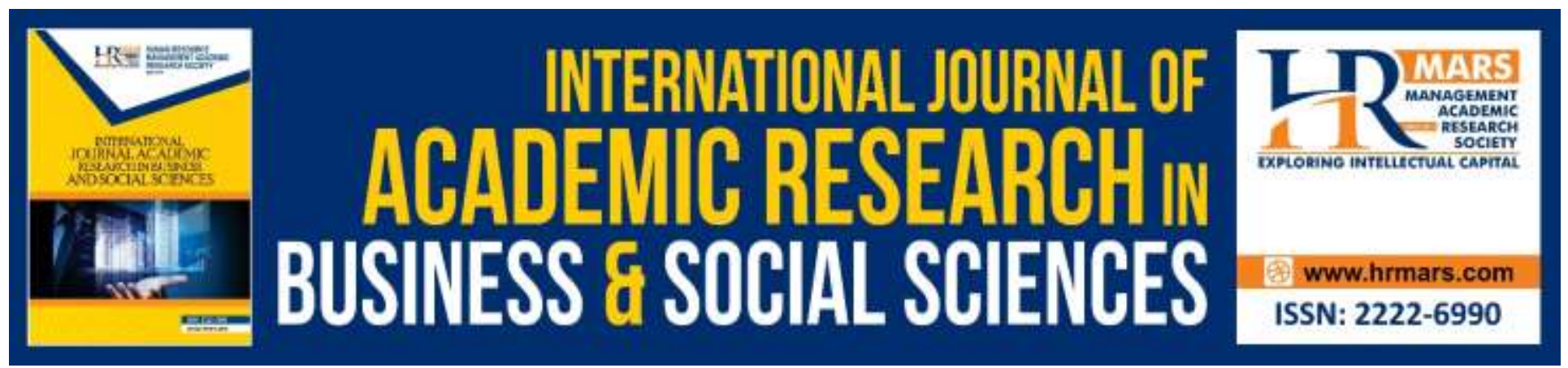

\title{
Organizational Restructuring: Lesson Learned From Tourism Malaysia
}

Ahmad Fadhly Arham, Nor Sabrena Norizan, Ahmad Khairuman, Md Hasim,
Mohamad Daim Darson, Nadhirah Syafiqah Mohd Faizal

To Link this Article: http://dx.doi.org/10.6007/IJARBSS/v8-i8/4431

DOI: 10.6007/IJARBSS/v8-i8/4431

Received: 10 June 2018, Revised: 23 June 2018, Accepted: 29 July 2018

Published Online: 08 August 2018

In-Text Citation: (Arham et al., 2018)

To Cite this Article: Arham, A. F., Norizan, N. S., Khairuman, A., Hasim, M., Darson, M. D., \& Faizal, N. S. M. (2018). Organizational Restructuring: Lesson Learned From Tourism Malaysia. International Journal of Academic Research in Business and Social Sciences, 8(8), 42-49.

Copyright: (c) 2018 The Author(s)

Published by Human Resource Management Academic Research Society (www.hrmars.com)

This article is published under the Creative Commons Attribution (CC BY 4.0) license. Anyone may reproduce, distribute, translate and create derivative works of this article (for both commercial and non-commercial purposes), subject to full attribution to the original publication and authors. The full terms of this license may be seen at: http://creativecommons.org/licences/by/4.0/legalcode

Vol. 8, No. 8, August 2018, Pg. $42-49$

http://hrmars.com/index.php/pages/detail/IJARBSS

JOURNAL HOMEPAGE

Full Terms \& Conditions of access and use can be found at http://hrmars.com/index.php/pages/detail/publication-ethics 


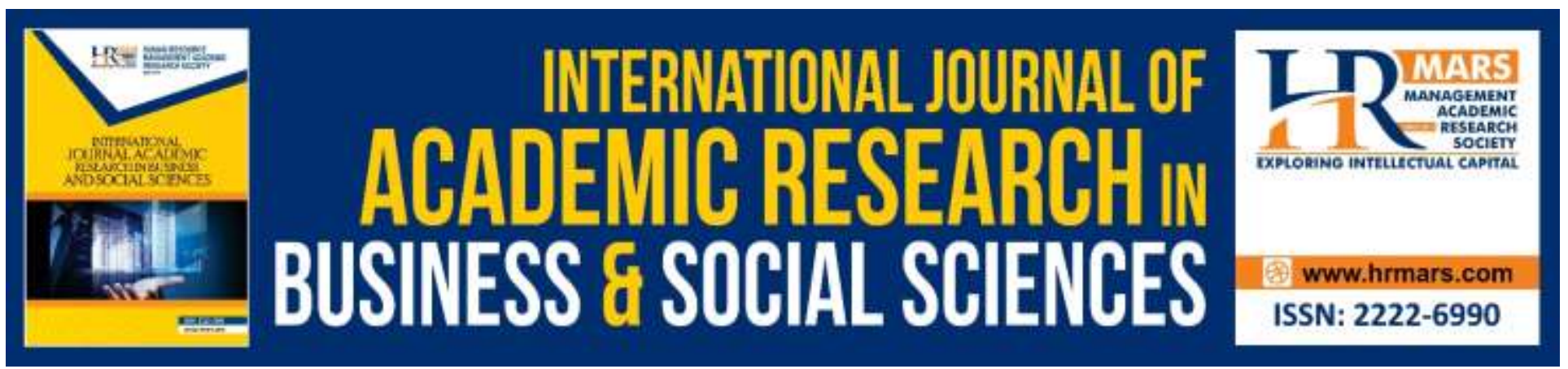

\title{
Organizational Restructuring: Lesson Learned From Tourism Malaysia
}

\author{
Ahmad Fadhly Arham, Nor Sabrena Norizan, Ahmad Khairuman Md \\ Hasim, Mohamad Daim Darson, Nadhirah Syafiqah Mohd Faizal \\ Universiti Teknologi MARA, Melaka, Malaysia
}

\begin{abstract}
Any form of organizational changes creates impact towards organizational resources, especially towards the employees. Transformation strategy via restructuring taken by organization needs to be implemented properly to avoid any negative impact towards organizational performance. This is the core interest of this paper. It is intended to identify the factors that employees perceived as important to them to maintain their organizational commitment due to the structuring strategy. Based on quantitative findings gathered from 138 respondents who were affected by the restructuring strategy, employees perceived that their commitment is still high upon receiving the managerial decision. The correlation analysis concluded that, training, communication and decisionmaking are all positively correlated towards organizational commitment. The implications and suggestions are also discussed.
\end{abstract}

Keywords: Organizational Commitment, Restructuring.

\section{Introduction}

Tourism Malaysia had announced that it will close down its state offices throughout the country (The STAR, 2017). This announcement was made by Tourism and Culture Minister, Datuk Seri Mohamed Nazri Abdul Aziz. However, this will not involve any termination of services of its employees of the 14 tourism offices. The plan is to absorb them into the ministry's headquarters and other departments. David \& David (2017) had explained that, in order for organizations to achieve a successful implementation of restructuring strategy, a supportive culture needs to be developed. This can be done through altering some of the existing organization cultures such as training, making positive reinforcements and revising mission and vision.

Organizational restructuring happens in many organizations and it is part of strategic move that the organizations need to take in order for them to continue to survive. According to Pfeffer (1994), for organizational change to occur, management within organization is undergoing internal and external pressure. Such pressure includes political and social events and government laws and regulations. 
According to Girod \& Karim (2017), restructuring can be defined as the most crucial method to redesign the organization, and to focus on re-configuring the organizational units (specifically the large units). Restructuring results in increasing the operating efficiency and cost saving. However, it also may result in negative outcomes such as demoralization and traumatization of employees.

Due to restructuring, employees' commitment towards the organization maybe affected. There are many possible implications that may affect them financially and non-financially. To the employees, this strategy may include additional costs on relocation, changes in the mode of commuting, new job scope and responsibilities, acquiring of new skills, learning of new organizational cultures and the impact on family matters.

Past research has demonstrated that restructuring can have a negative influence on employees' wellbeing; even to those who still remained and kept in the organization (Widerszal-Bazyl \& Mockałło, 2015). Thus, the motivation of this research is to investigate the potential factors that matters as perceived by the 'affected employees' due to the structuring strategy by the ministry; that may have impacted their organizational commitment. The outcomes of this research are important to the field of Strategic Management as well as Strategic Tourism Management as it may serve as preliminary data on understanding the impact of such decision towards the ministry as well as the tourism industry as a whole. An understanding of this scenario also will help the organization to focus on factors that matters towards the employees. It also would ease down the uncertainty and anxiety felt by the employees during the transition phase. The novelty of this research lies on its being the first to initiate information of a newly announced strategy by the Tourism Malaysia.

\section{Literature Review}

Organizational commitment is referred to as employee's willingness to provide extra effort within the organization (Bateman \& Strasser, 1984). Mowday, Porter \& Steers (1982) explained organizational commitment as an attitude that demonstrates the nature and quality of the relationship between an organization and its subordinates.

Finding also shows the higher the commitment of employees, the higher the outcomes such as job satisfaction, motivation and regularity in work (Benette \& Durkin, 2000). Besides, (Robbin \& Langton, 2001) in their previous studies mentioned that those employees who have high level of organizational commitment will reduce the level of stress during the organizational change and they will understand and deal with changes as to make it success.

Previous study by Noordin, Omar, Sehan and Idrus (2010) had mentioned that positive organizational climate acts as a catalyst that emphasis organizational commitment. Meaning to say, perhaps in the presence of positive organizational climate such as high involvement in decision making, transparent communication among employees and training provided perhaps would increase level of organizational commitment among employees.

\section{Decision-making, Communication and Training}

Steers and Porter (1974) in a previous study had reported that there is a positive relationship between participation in decision making with the perceptions of the organization including 
INTERNATIONAL JOURNAL OF ACADEMIC RESEARCH IN BUSINESS AND SOCIAL SCIENCES

Vol. 8, No. 8, August 2018, E-ISSN: 2222-6990 @ 2018 HRMARS

commitment. This conclusion was confirmed by Welsch and Lavan (1981) that organizational commitment and participation in decision making are positively related.

Brand and Wilson (2000) in a previous study mentioned that quality of communication has a direct effect on the changes of organization structure. They also suggested that it is important for the organization to have a complete plan and the changes must be informed to all the stakeholders. Perhaps, all level of organization function.

According to Thang (2009), knowledge and skills of employees have become the important elements for organization to remain competitive, increase organization performance and to become innovative. In short, to achieve competitive advantage, the basic source of organization is human resource capital.

Bashir and Long (2015) stated that training is a learning process provided by the management or the expertise given to the employees to have learning opportunities in a proper manner which the main purpose is to develop employee's knowledge and skills and attitude needed by the organization in achieving their goals.

\section{Research Framework}

Based from the literature, the following framework is developed.

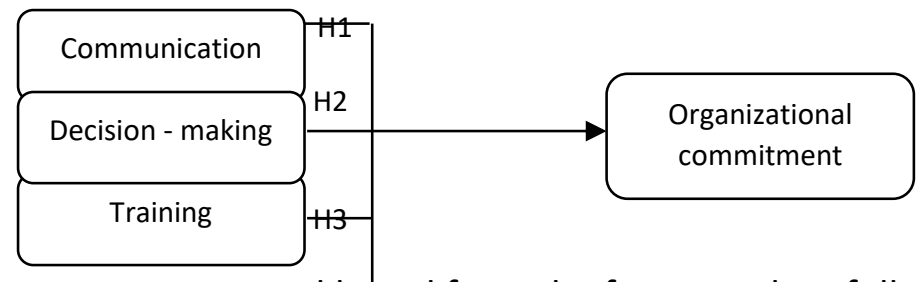

Three hypotheses were proposed based from the framework as follows:

H1: There is a significant relationship between communication and organizational commitment;

$\mathrm{H} 2$ : There is a significant relationship between decision-making and organizational commitment;

H3: $\quad$ There is a significant relationship between training and organizational commitment.

\section{Research Method}

This research adopted a quantitative approach. Currently, there were about 175 employees in all 14 states. This study also adopted a census sample in which all 175 employees were included and 175 questionnaires were distributed.

The survey questionnaire was distributed via email. First, an invitation email to participate in the research was sent out to each state office. After two weeks, a reminder email was sent out and since the feedbacks obtained were not encouraging, one of the Managers in one of the state offices was approached to assist with data collection. Another email was sent out by this Manager to encourage more participation from the employees at state offices. Through this approach, this research was able to obtain more feedbacks from the respondents. According to Sekaran \& Bougie (2013), if the total population $(N)$ is 180 , the most appropriate sample size $(S)$ is 123 . Thus, this research was able to obtain the minimum number of sample required as the number of returned questionnaire was 138. Thus, the response rate of this study is $79 \%$. 
INTERNATIONAL JOURNAL OF ACADEMIC RESEARCH IN BUSINESS AND SOCIAL SCIENCES

Vol. 8, No. 8, August 2018, E-ISSN: 2222-6990 @ 2018 HRMARS

The measurements for organizational commitment were adopted from Mowday, Steers and Porter (1979). The measurements for participative decision making, communication and training were adopted form Furnham and Goodstein OCQ (1997). A Likert Scale of 1 to 5 was used. 1 indicating a strongly disagree and 5 indicating a strongly agree perception of the respondents to each measurement item.

\section{Findings}

\section{Reliability}

The results from Cronbach analysis indicated that the internal consistency of all variables were acceptable level ( $n=138$ ). Organizational commitment reported a $\alpha=0.687$ (4 items), communication reported a $\alpha=0.664$ ( 4 items), decision making reported a $\alpha=0.829$ (4 items) and training reported a $\alpha=0.878$ ( 4 items)

\section{Descriptive Analysis}

The following table presents the descriptive analysis of the variables.

Table 1.0: Mean analysis

\begin{tabular}{|c|c|c|}
\hline Variables & Mean & Standard Deviation \\
\hline Organizational Commitment & 3.96 & .680 \\
\hline Communication & 3.10 & .790 \\
\hline Decision-making & 3.20 & .800 \\
\hline Training & 3.59 & 1.00 \\
\hline
\end{tabular}

From the table, the respondents perceive that, due to the restructuring in which will involve relocation into different job function and responsibilities, training is perceived as the most important factor than communication and decision making factor. The level of mean for organizational commitment is reported at $\mathrm{M}=3.96(\mathrm{SD}=.680)$. It means that employees perceived they are still highly committed towards the organization.

\section{Correlational Analysis}

Table 2.0: Correlation Analysis $(n=138)$

\begin{tabular}{|l|c|c|c|}
\hline & Communication & $\begin{array}{c}\text { Decision- } \\
\text { making }\end{array}$ & Training \\
\hline Person Correlation & $.387^{* *}$ & $.352^{* *}$ & $.609 * *$ \\
Sig. (2-tailed) & .000 & .000 & .000 \\
Strength & Weak & Weak & Moderate \\
\hline
\end{tabular}

** Correlation is significant at the 0.01 level (2-tailed)

Based on Table 2.0, there is a positive and weak relationship between communication and organizational commitment ( $r=0.387)$; and this relationship is significant at 0.01 level. Thus, $\mathrm{H} 1$ is supported. The results also finds support for $\mathrm{H} 2$, in which there is positively weak relationship between decision-making and organizational commitment $(r=0.352)$; and this relationship is significant at the 0.01 level. Thus, $\mathrm{H} 2$ is supported. There is also a positively moderate correlation 
INTERNATIONAL JOURNAL OF ACADEMIC RESEARCH IN BUSINESS AND SOCIAL SCIENCES

Vol. 8, No. 8, August 2018, E-ISSN: 2222-6990 @ 2018 HRMARS

$(r=0.609)$ between training and organizational commitment and this relationship is also significant at 0.01 level. Thus, $\mathrm{H} 3$ is supported.

\section{Discussion \& Conclusion}

It can be concluded that, employees perceived that they are still committed $(M=3.96, S D=0.68$ ) despite a major restructuring announcement being made. They also perceived that, among the three independent variables, training is regarded as the most important, followed by decision-making and communication.

Correlationally, all independent variables are significantly correlated towards organizational commitment, thus all hypotheses were supported. Among the three independent variables, training has a moderate strength relationship towards organizational commitment. Whereas, the strength of the relationships between communication and decision-making towards organizational commitment is weak.

Training is an important factor that can be seen as crucial after restructuring. As mentioned earlier, the changes will cause some of the employees to be transferred to another unit. For example; those who were under administration will probably being transfer as Tourism Officer. Thus, perhaps they are concerned about whether they can still perform their duties accordingly in the new position. This is supported by literature that states that training is important upon any organizational transformation (Rubin, Oehler \& Adair, 2013). These authors have urged the organization to provide necessary training to employees after major changes that took place as well as resources for them to accomplish new task successfully.

The success of changes in organizational structure is dependent upon the quality of communication (Brand and Wilson 2000). Besides, they also mentioned that it is important for the organization to have a complete plan and the changes must be informed to all stakeholders. This shows that communication is also one of the important elements that needs to be considered during restructuring. Without proper communication regarding the changes, it creates uneasy peace of mind and perhaps may lead to demotivation towards work.

Effective of the communication is influencing the decision making process. When the communication is not effective, employees may find it hard to cope with the changes and thus this will create another level of difficulty in decision-making (Blenko, Mankins \& Rogers, 2010).

As a conclusion, organization needs to understand what matters to the employees during the restructuring process. This is due to the fact that restructuring brings changes in organizational climate. Tourism Malaysia needs to focus on how to train them in their new post to minimize the impact of their action. This paper communicates that, the employees perception and the empirical finding concluded that training is most important factor to be considered upon restructuring. To minimize the effect on employees' well-being, as discussed by Widerszal-Bazyl \& Mockałło (2015) \& Rubin, Oehler \& Adair (2013), the organization needs to provide necessary training and resources to make the transition towards transformation a successful decision. It is recommended that, a deeper analysis is conducted in the future to really assess the effect of each of this factor towards 
INTERNATIONAL JOURNAL OF ACADEMIC RESEARCH IN BUSINESS AND SOCIAL SCIENCES

Vol. 8, No. 8, August 2018, E-ISSN: 2222-6990 @ 2018 HRMARS

organizational commitment. Also, longitudinal data might also provide a thorough picture on the success of any transformation strategy by taken by the organization via restructuring.

\section{References}

Bashir, N., \& Long, C. S. (2015). The relationship between training and organizational commitment among academicians in Malaysia. Journal of Management Development, 34 (10), 1227-1245.

Bateman, T., \& Strasser, S. (1984). A longitudinal analysis of the antecedents of the Organizational Commitment. Academy of Management Journal, 21, 95-112.

Benette, H., \& Durkin, M. (2000). The effect of organizational change on employee Psychological attachment: An exploratory Study. Journal of Managerial Psychology,15, 126-147.

Blenko, M. W., Mankins, M. C., \&Rogers, P. (2010). The decision-driven organization. Harvard Business Review. 2010, 88, 54-62.

Brand, H. E., \& Wilson, J. (2000). The Impact of Organizational Restructuring on Organization Climate and Employee Attitude. Journal of Human Resource Management, 3(1), 97-108.

David, F. R., \& David, F. R. (2017). Strategic Management: A Competitive Advantage Approach, Concepts and Cases (16th ed.). Essex, ENG: Pearson.

Furnham, F. (1997). Thepsychology of behavior at work: The individual in the organization.-Sussex, UK: Psychology Press.

Girod, S. J. G., \& Karim, S. (2017). Restructure or reconfigure? Harvard Business Review, MarchApril. Retrieved from https://hbr.org/2017/03/restructure-or-reconfigure.

Mowday, R. T., Steers, R. M., \& Porter, L. W. (1979). The Measurement of Organisational Commitment. Journal of Vocational Behaviour, 14, 224-247.

Mowday, R., Porter, L., \& Steers, R. (1982). Employee-Organization linkages: The Psychology of Commitment, Absenteeism, and Turnover. New York: Academic Press.

Noordin, F., Omar, S., Sehan, S., \& Idrus, S. (2010). Organizational Climate and Its Influence On Organizational Commitment. International Buisness \& Ecocomic Research Journal, 9(2), 1-9.

Pfeffer, J. (1994). Competitive advantage through people: Boston: Harvard Business School Press.

Robbin, S., \& Langton, N. (2001). Organizational Behavior: Concepts, Controversies And Applications (2nd ed.). Toranto: Prentice Hall Inc.

Rubin, D. P., Oehler, K., \& Adair, C. (2013). Managing employee engagement during times of change. Risk, Reinsurance, Human Resources. Aon Hewitt. Retrieved from http://www.aon.com/attachments/human-capitalconsulting/2013_Managing_Engagement_During_Times_of_Change_White_Paper.pdf

Sekaran, U., \& Bougie, R. (2013). Research methods for business: a skill-building approach (6th ed). Chichester, West Sussex: Wiley.

Steers, R. M., \& Porter, L. M. (1997). Motivation \& Work behaviour.New York: McGraw Hill.

Thang, N. N. (2009). Human resource training, organisational strategy and firm performance in emerging economies: the case of Vietnam. Ghent, Belgium: Ghent University.

The STAR. (2017).Tourism Malaysia offices nationwide closed to avoid job duplication. Retrieved from http://www.thestar.com.my/news/nation/2017/01/23/tourism-malaysiaofficesnationwide-closed-to-avoid-job-duplication.

Welsch, H., \& LaVan, H. (1981). Inter-relationships between Organizational Commitment and job characteristics, job Satisfaction, professional behaviour, and organizational climate. Human Relations, 34(12), 1079-1089. 
INTERNATIONAL JOURNAL OF ACADEMIC RESEARCH IN BUSINESS AND SOCIAL SCIENCES Vol. 8, No. 8, August 2018, E-ISSN: 2222-6990 @ 2018 HRMARS

Widerszal-Bazyl, M., \& Mockałło, Z. (2015). Do all types of restructuring threaten employees' wellbeing? An exploratory study. International Journal of Occupational Medicine and Environmental Health, 28(4), $689-706$. 